\title{
Front Matter: Volume 7063
}

, "Front Matter: Volume 7063," Proc. SPIE 7063, Interferometry XIV: Techniques and Analysis, 706301 (11 August 2008); doi: 10.1117/12.807652

SPIE Event: Optical Engineering + Applications, 2008, San Diego, California, United SPIE. States 


\section{PROCEEDINGS OF SPIE}

\section{Interferometry XIV: Techniques and Analysis}

Joanna Schmit

Katherine Creath

Catherine E. Towers

Editors

11-13 August 2008

San Diego, California, USA

Sponsored and Published by

SPIE

Volume 7063 
The papers included in this volume were part of the technical conference cited on the cover and title page. Papers were selected and subject to review by the editors and conference program committee. Some conference presentations may not be available for publication. The papers published in these proceedings reflect the work and thoughts of the authors and are published herein as submitted. The publisher is not responsible for the validity of the information or for any outcomes resulting from reliance thereon.

Please use the following format to cite material from this book:

Author(s), "Title of Paper," in Interferometry XIV: Techniques and Analysis, edited by Joanna Schmit, Katherine Creath, Catherine E. Towers, Proceedings of SPIE Vol. 7063 (SPIE, Bellingham, WA, 2008) Article CID Number.

ISSN 0277-786X

ISBN 9780819472830

Published by

SPIE

P.O. Box 10, Bellingham, Washington $98227-0010$ USA

Telephone +1 3606763290 (Pacific Time) · Fax +1 3606471445

SPIE.org

Copyright (c) 2008, Society of Photo-Optical Instrumentation Engineers

Copying of material in this book for internal or personal use, or for the internal or personal use of specific clients, beyond the fair use provisions granted by the U.S. Copyright Law is authorized by SPIE subject to payment of copying fees. The Transactional Reporting Service base fee for this volume is $\$ 18.00$ per article (or portion thereof), which should be paid directly to the Copyright Clearance Center (CCC), 222 Rosewood Drive, Danvers, MA 01923. Payment may also be made electronically through CCC Online at copyright.com. Other copying for republication, resale, advertising or promotion, or any form of systematic or multiple reproduction of any material in this book is prohibited except with permission in writing from the publisher. The CCC fee code is 0277-786X/08/\$18.00.

Printed in the United States of America.

Publication of record for individual papers is online in the SPIE Digital Library.

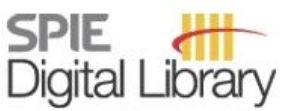

SPIEDigitalLibrary.org

Paper Numbering: Proceedings of SPIE follow an e-First publication model, with papers published first online and then in print and on CD-ROM. Papers are published as they are submitted and meet publication criteria. A unique, consistent, permanent citation identifier (CID) number is assigned to each article at the time of the first publication. Utilization of CIDs allows articles to be fully citable as soon they are published online, and connects the same identifier to all online, print, and electronic versions of the publication. SPIE uses a six-digit CID article numbering system in which:

- The first four digits correspond to the SPIE volume number.

- The last two digits indicate publication order within the volume using a Base 36 numbering system employing both numerals and letters. These two-number sets start with $00,01,02,03,04,05$, 06, 07, 08, 09, OA, OB ... 0Z, followed by 10-1Z, 20-2Z, etc.

The CID number appears on each page of the manuscript. The complete citation is used on the first page, and an abbreviated version on subsequent pages. Numbers in the index correspond to the last two digits of the six-digit CID number. 


\section{Contents}

ix Conference Committee

xi Introduction

xv Advanced and shaped light fields for the biosciences (Invited Paper)(Abstract Only) [7063-02]

K. Dholakia, Univ. of St. Andrews (United Kingdom)

\section{SESSION 1 ON THE FRINGE}

706302 It's a (meta)material world! The final frontier? (Invited Paper) [7063-01]

A. D. Boardman, R. C. Mitchell-Thomas, Y. G. Rapoport, N. J. King, Univ. of Salford (United Kingdom)

706303 Advanced and shaped light fields for the biosciences (Invited Paper) [7063-02]

K. Dholakia, Univ. of St. Andrews (United Kingdom)

706304 Coarse frequency comb interferometry (Invited Paper) [7063-03]

J. Schwider, Institute of Optics, Information and Photonics, Max Planck Research Group (Germany)

706305 Generalized quantitative approach to two-beam fringe visibility (coherence) with different polarizations and frequencies [7063-04]

C. Roychoudhuri, Univ. of Connecticut (United States) and Femto Macro Continuum

(United States); A. M. Barootkoob, Consultant (United States)

\section{SESSION 2 SPATIAL AND SHEARING TECHNIQUES}

706306 Spatially phase-shifted digital speckle pattern interferometry (SPS-DSPI) and cryogenic structures: recent improvements (Invited Paper) [7063-05]

P. Blake, NASA Goddard Space Flight Ctr. (United States); P. Greenfield, W. Hack,

J. T. Miller, I. Busko, B. Saif, B. Eegholm, Space Telescope Science Institute (United States);

R. Keski-Kuha, NASA Goddard Space Flight Ctr. (United States); M. Bluth, ATK Spacecraft

Systems (United States)

706307 Instantaneous phase-shift Fizeau interferometer utilizing a synchronous frequency shift mechanism [7063-06]

B. Kimbrough, E. Frey, J. Millerd, 4D Technology Corp. (United States)

706308 Development of a multi-component shearography instrument for surface strain measurement on dynamic objects [7063-07]

D. Francis, S. W. James, R. P. Tatam, Cranfield Univ. (United Kingdom) 
706309 Optical wavefront sensor based on sub-wavelength metallic structures [7063-08] R. Haïdar, B. Toulon, ONERA/DOTA (France); G. Vincent, ONERA/DOTA (France) and LPN/CNRS (France); S. Collin, LPN/CNRS (France); S. Velghe, Phasics (France); J. Primot, ONERA/DOTA (France); J.-L. Pelouard, LPN/CNRS (France)

\section{SESSION $3 \quad$ SPECKLE AND UNWRAPPING TECHNIQUES}

7063 OA A dynamic in-plane deformation measurement using virtual speckle patterns (Invited Paper) [7063-09]

Y. Arai, R. Shimamura, Kansai Univ. (Japan); S. Yokozeki, Jyouko Applied Optics Lab. (Japan)

$7063 \mathrm{OB}$ The spatial degree of polarization and the first-order statistical properties of polarization speckle [7063-10]

W. Wang, Heriot-Watt Univ. (United Kingdom); A. Matsuda, The Univ. of ElectroCommunications (Japan); S. G. Hanson, Technical Univ. of Denmark (Denmark); M. Takeda, The Univ. of Electro-Communications (Japan)

7063 OC Lockin-speckle-interferometry for non-destructive testing [7063-11]

P. Menner, H. Gerhard, G. Busse, Univ. of Stuttgart (Germany)

7063 OD Denoising of digital speckle pattern interferometry fringes by means of Bidimensional Empirical Mode Decomposition [7063-12]

M. B. Bernini, Consejo Nacional de Investigaciones Científicas y Técnicas (Argentina) and Univ. Nacional de Rosario (Argentina); A. Federico, Instituto Nacional de Tecnología Industrial (Argentina); G. H. Kaufmann, Consejo Nacional de Investigaciones Científicas y Técnicas (Argentina) and Univ. Nacional de Rosario (Argentina)

7063 OE Filtering-based phase unwrapping [7063-13]

K. Qian, W. Gao, H. Wang, Nanyang Technological Univ. (Singapore)

\section{SESSION 4 DIGITAL HOLOGRAPHY AND HETERODYNE TECHNIQUES}

7063 OF Investigations and improvements of digital holographic tomography applied for 3D studies of transmissive photonics microelements (Invited Paper) [7063-14] M. Kujawinska, A. Jozwicka, T. Kozacki, Warsaw Univ. of Technology (Poland)

7063 OG Strain distribution measurement by digital holographic interferometry using three spherical waves [7063-15]

M. Fujigaki, K. Shiotani, R. Kido, Y. Morimoto, Wakayama Univ. (Japan)

$7063 \mathrm{OH} \quad$ Modeling and optical characterization of vibrating micro- and nanostructures (Invited Paper) [7063-16]

A. Aksnes, E. Leirset, H. Martinussen, H. E. Engan, Norwegian Univ. of Science and Technology (Norway)

7063 Ol Real-time vibration amplitude and phase imaging with heterodyne interferometry and correlation image sensor [7063-17]

S. Sato, T. Kurihara, S. Ando, The Univ. of Tokyo (Japan) 
7063 oJ Laser confocal feedback profilometry [7063-18]

X. Wan, S. Zhang, Z. Ren, Tsinghua Univ. (China)

\section{SESSION $5 \quad$ PHASE ANALYSIS AND FRINGE PROJECTION TECHNIQUES}

7063 OK New algorithms and error analysis for sinusoidal phase shifting interferometry (Invited Paper) [7063-19]

P. J. de Groot, L. L. Deck, Zygo Corp. (United States)

$7063 \mathrm{OL} \quad$ Iterative algorithm for phase shifting interferometry with finite bandwidth illumination [7063-20]

F. Munteanu, J. Schmit, Veeco Instruments Inc. (United States)

7063 OM Simultaneous geometry and color texture acquisition using a single-chip color camera [7063-21]

S. Zhang, lowa State Univ. (United States); S.-T. Yau, Harvard Univ. (United States)

$7063 \mathrm{ON} \quad$ Shape and colour measurement of colourful objects by fringe projection [7063-22]

Z. Zhang, C. E. Towers, D. P. Towers, Univ. of Leeds (United Kingdom)

706300 Moiré topography using a liquid-crystal-grating based frequency modulation technique [7063-23]

F. Kobayashi, Y. Otani, Tokyo Univ. of Agriculture and Technology (Japan); T. Yoshizawa, Saitama Medical Univ. (Japan)

\section{SESSION 6 THICKNESS MEASUREMENT}

7063 OP Fizeau interferometer for quasi parallel optical plate testing [7063-24]

A. Styk, K. Patorski, Warsaw Univ. of Technology (Poland)

$70630 Q \quad$ Angle-resolved reflectometer for thickness measurement of multi-layered thin-film structures [7063-25]

W.-D. Joo, J. You, Y.-S. Ghim, S.-W. Kim, Korea Advanced Institute of Science and Technology (Korea, Republic of)

$7063 \mathrm{OR} \quad$ Uncertainty analysis on the absolute thickness of a cavity using a commercial wavelength scanning interferometer [7063-26]

A. Suratkar, Y.-S. Ghim, A. Davies, Univ. of North Carolina at Charlotte (United States)

7063 OS Measurement of absolute optical thickness distribution of a mask-glass by wavelength tuning interferometry [7063-27]

K. Hibino, National Institute of Advanced Industrial Science and Technology (Japan); K. Yangjin, Univ. of Tokyo (Japan); Y. Bitou, S. Ohsawa, National Institute of Advanced Industrial Science and Technology (Japan); N. Sugita, M. Mitsuishi, Univ. of Tokyo (Japan) 
7063 OT Dual frequency sweeping interferometry with range-invariant accuracy for absolute distance metrology (Invited Paper) [7063-28]

A. Cabral, J. M. Rebordão, M. Abreu, INETI - Instituto Nacional de Engenharia, Tecnologia e Inovação (Portugal)

7063 OU Micro Fabry-Perot sensor for surface measurement [7063-29]

A. Brunfeld, G. Toker, M. T. Roscrow, Jr., B. Clark, Xyratex International Inc. (United States)

$70630 \mathrm{~V}$ Optimum wavelength selection for the method of excess fractions [7063-30]

K. Falaggis, D. P. Towers, C. E. Towers, Univ. of Leeds (United Kingdom)

7063 OW Multiple wavelength interferometry for surface profiling [7063-47]

U. Paul Kumar, N. Krishna Mohan, M. P. Kothiyal, Indian Institute of Technology Madras (India)

7063 OX A hybrid technique for ultra-high dynamic range interferometry [7063-32]

K. Falaggis, D. P. Towers, C. E. Towers, Univ. of Leeds (United Kingdom)

\section{SESSION 8 COMPLEX STRUCTURES AND ULTRA SHORT PULSE MEASUREMENT}

7063 OY Surface profile detection of nanostructures using a Mueller matrix polarimeter [7063-33]

Y. Otani, T. Kuwagaito, Y. Mizutani, Tokyo Univ. of Agriculture and Technology (Japan)

$7063 \mathrm{OZ}$ 3D profilometer employing white-light interferometry for microstructures with large-bevel inclines in brightness-enhanced films [7063-34]

W. C. Wang, Y. J. Su, S. H. Kuo, Industrial Technology Research Institute (Taiwan)

706310 Surface metrology of silicon wafers using a femtosecond pulse laser [7063-35]

T. Kwon, K.-N. Joo, S.-W. Kim, Korea Advanced Institute of Science and Technology

(Korea, Republic of)

$706311 \quad$ Noncollinear autocorrelation with radially symmetric nondiffracting beams [7063-36]

S. Huferath-von Luepke, Bremen Institute of Applied Beam Technology (Germany);

V. Kebbel, bwm GmbH (Germany); M. Bock, S. Kumar Das, R. Grunwald, Max-Born-Institute for Nonlinear Optics and Short-Pulse Spectroscopy (Germany)

SESSION 9 TESTING OF ASPHERIC SURFACES

706312 Testing of a diamond-turned off-axis parabolic mirror (Invited Paper) [7063-37]

J. Burke, CSIRO Materials Science and Engineering-Australian Ctr. for Precision Optics

(Australia); K. Wang, A. Bramble, Macquarie Univ. (Australia)

706313 Distortion mapping correction in aspheric null testing [7063-38]

M. Novak, C. Zhao, J. H. Burge, College of Optical Sciences, The Univ. of Arizona

(United States) 
706314 Interferometric null test of a parabolic reflector generating a Hertzian dipole field [7063-39] G. Leuchs, K. Mantel, A. Berger, H. Konermann, M. Sondermann, U. Peschel, N. Lindlein, J. Schwider, Institute of Optics, Information, and Photonics, Univ. of Erlangen/Nuremberg (Germany)

706315 Optical testing by means of one-dimensional interferograms performed with a pointdiffraction interferometer [7063-41]

L. Rodríguez-Castillo, F. S. Granados-Agustín, A. Cornejo-Rodríguez, Instituto Nacional de Astrofísica, Óptica y Electrónica (Mexico)

\section{SESSION 10 TESTING OF ASPHERIC SURFACES AND WAVEFRONT COLLIMATION}

706316 Stitching of off-axis sub-aperture null measurements of an aspheric surface [7063-40]

C. Zhao, J. H. Burge, College of Optical Sciences, The Univ. of Arizona (United States)

706317 Measurements of aspheric surfaces [7063-56]

P. Szwaykowski, R. Castonguay, Engineering Synthesis Design (United States)

706318 Wide dynamic beam size range lateral-shear interferometer [7063-45]

K. U. Hii, K. H. Kwek, Univ. of Malaya (Malaysia)

\section{POSTER SESSION}

706319 Interferometer design for optical stochastic cooling demonstration at Bates [7063-42]

J. Hays-Wehle, W. Franklin, F. X. Kärtner, J. van der Laan, R. Milner, A. Siddiqui, C. Tschalär,

F. Wang, Massachusetts Institute of Technology (United States)

$70631 \mathrm{~A}$ Optical heterodyne laser encoder for in-plane nanopositioning [7063-48]

C.-C. Wu, C.-C. Hsu, Industrial Technology Research Institute (Taiwan); J.-Y. Lee, National Central Univ. (Taiwan); C.-Y. Liu, Industrial Technology Research Institute (Taiwan)

7063 1B Temporal phase detection of interferograms without frequency carrier [7063-49]

J. C. Estrada, M. Servin, D. Arroyo, Ctr. de Investigaciones en Óptica (Mexico)

7063 1C Spatial coherence wavelets and the phase-space representation of holography [7063-51] R. Betancur, R. Castañeda, J. Restrepo, Univ. Nacional de Colombia Sede Medellin (Colombia)

7063 1D Method for distant diagnostics of layered media inner structure [7063-53] A. L. Kalyanov, V. V. Lychagov, D. V. Lyakin, Saratov State Univ. (Russia); V. P. Ryabukho, Saratov State Univ. (Russia) and Institute of Precision Mechanics and Control (Russia)

7063 IE Dynamic measurement of strain in test specimen by fringe projection [7063-54]

A. León-Huerta, A. Martinez, J. A. Rayas, Ctr. de Investigaciones en Óptica (Mexico);

R. Cordero, Univ. de Santiago de Chile (Chile)

7063 IF An ESPI technique based on panoramic interferometry with paraboloid mirrors [7063-55] A. Soto, J. B. Hurtado-Ramos, L. Reséndiz, J. J. González Barbosa, Ctr. de Investigación en Ciencia Aplicada y Tecnología Avanzada-IPN Unidad Querétaro (Mexico)

Author Index 
Downloaded From: https://www.spiedigitallibrary.org/conference-proceedings-of-spie on 26 Apr 2023

Terms of Use: https://www.spiedigitallibrary.org/terms-of-use 


\title{
Conference Committee
}

\author{
Conference Chairs
}

Joanna Schmit, Veeco Instruments Inc. (United States)

Katherine Creath, Optineering (United States) and College of Optical Sciences, The University of Arizona (United States)

Catherine E. Towers, University of Leeds (United Kingdom)

Program Track Chair

Katherine Creath, Optineering (United States) and College of Optical Sciences, The University of Arizona (United States)

Program Committee

Astrid Aksnes, Norwegian University of Science and Technology (Norway)

Armando Albertazzi Goncalves, Jr., Universidade Federal de Santa Catarina (Brazil)

Gordon M. Brown, Optical Systems Engineering (United States)

Jan Burke, Commonwealth Scientific and Industrial Research Organisation, Materials Science and Engineering (Australia)

Werner P. O. Jüptner, Bremer Institut für Angewandte Strahltechnik (Germany)

Guillermo H. Kaufmann, Universidad Nacional de Rosario (Argentina)

Seung-Woo Kim, Korea Advanced Institute of Science and Technology (Korea, Republic of)

Mahendra P. Kothiyal, Indian Institute of Technology Madras (India)

Malgorzata Kujawinska, Politechnika Warszawska (Poland)

Mike McCarthy, National Physical Laboratory (United Kingdom)

Michael B. North Morris, 4D Technology Corporation (United States)

Erik L. Novak, Veeco Instruments Inc. (United States)

Jiri Novák, Czech Technical University in Prague (Czech Republic)

Wolfgang Osten, Universität Stuttgart (Germany)

Yukitoshi Otani, Tokyo University of Agriculture and Technology (Japan)

Jérôme Primot, ONERA (France)

Manuel Servín, Centro de Investigaciones en Óptica, A.C. (Mexico)

H. Philip Stahl, NASA Marshall Space Flight Center (United States)

Mitsuo Takeda, The University of Electro-Communications (Japan)

Song Zhang, Harvard University (United States) 
Session Chairs

1 On the Fringe

Katherine Creath, Optineering (United States) and College of Optical

Sciences, The University of Arizona (United States)

2 Spatial and Shearing Techniques

Mitsuo Takeda, The University of Electro-Communications (Japan)

3 Speckle and Unwrapping Techniques

Catherine E. Towers, University of Leeds (United Kingdom)

4 Digital Holography and Heterodyne Techniques

Werner P. O. Jüptner, Bremer Institut für Angewandte Strahltechnik (Germany)

5 Phase Analysis and Fringe Projection Techniques

Jan Burke, Commonwealth Scientific and Industrial Research Organisation, Materials Science and Engineering (Australia)

6 Thickness Measurement

Astrid Aksnes, Norwegian University of Science and Technology (Norway)

$7 \quad$ Multi Wavelength Interferometry

Johannes Schwider, Friedrich-Alexander-Universität ErlangenNürnberg (Germany)

8 Complex Structures and Ultra Short Pulse Measurement

Joanna Schmit, Veeco Instruments Inc. (United States)

9 Testing of Aspheric Surfaces

Seung-Woo Kim, Korea Advanced Institute of Science and Technology (Korea, Republic of)

10 Testing of Aspheric Surfaces and Wavefront Collimation

Seung-Woo Kim, Korea Advanced Institute of Science and Technology (Korea, Republic of) 


\section{Introduction}

We thank SPIE, the program committee, the authors, and everyone attending this conference. SPIE continues to provide a forum for exchange of ideas and dissemination of the latest research in interferometry and related fields. As a community we come together at conferences such as this one to share not only our work, but also our professional vision. We reacquaint ourselves with old friends and meet new colleagues. The value of these conferences comes from both the professional insight we gain and the relationships we foster.

Interferometry XIV, which is a continuation of the Interferometry series, consists of two complementary conferences, one dedicated to Techniques and Analysis and the other to Applications. These two conferences present recent developments in analyses and techniques that use interference and projection fringes for highly precise measurements of different objects and their application in a wide range of systems. The proceedings of the two conferences comprising Interferometry XIV are published in two separate volumes as Interferometry XIV: Techniques and Analysis (SPIE Proceedings Vol. 7063) and Interferometry XIV: Applications (SPIE Proceedings Vol. 7064).

The growing demand for accurate and repeatable measurements of increasingly complex devices, especially in the semiconductor and MEMS industries as well as biological and space sciences, has driven the field of optical metrology to develop innovative techniques that provide fast, precise, real-time assessments of industrial products. While the range of techniques and technologies in interferometry is already vast, researchers strive to find solutions to new challenges that help make invisible things visible and to extend our vision further into outer space as well as into the nano-world.

This conference on Interferometric Techniques and Analysis highlights developments in surface metrology, digital holography, speckle, pulsed and polarization techniques, temporal and spatial phase shifting, low coherence interferometry, multiple wavelength, and fringe projection techniques. Other topics include new developments in vibration insensitive techniques and techniques for the measurement of aspheric surfaces, film thicknesses, surface motion, and stress. In addition, we spotlight cutting-edge papers on optical fields manipulation in a session titled "On the Fringe."

We are pleased to present a conference with such a large number of excellent papers. This proceedings volume contains 50 papers presented at the SPIE Optics and Photonics Meeting in San Diego on August 11-13, 2008. 43 of these papers were presented orally. These papers represent the work of researchers from 20 countries and four continents with invited speakers from the United Kingdom, Japan, Germany, the United States, Poland, Norway, Portugal, and Australia. 
During the last conference we had a great time choosing our favorite fringe patterns from those submitted by attendees. The favorite turned out to be distorted fringes reflected from a water surface and then analyzed by the fringe reflection technique presented by Thorsten Bothe from BIAS, Germany (Bremer Institute für Angewandte Strahltechnik) (see Figs. 1 and 2).

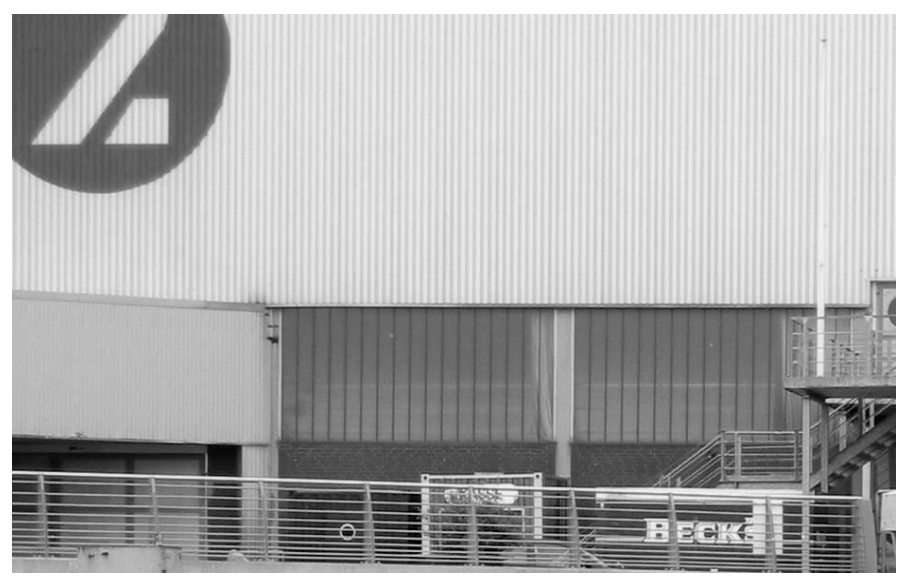

Fig.1 Periodic line structure on the side of the building. Top part of winning Fringe Art competition photo taken by T. Bothe from BIAS, Germany.

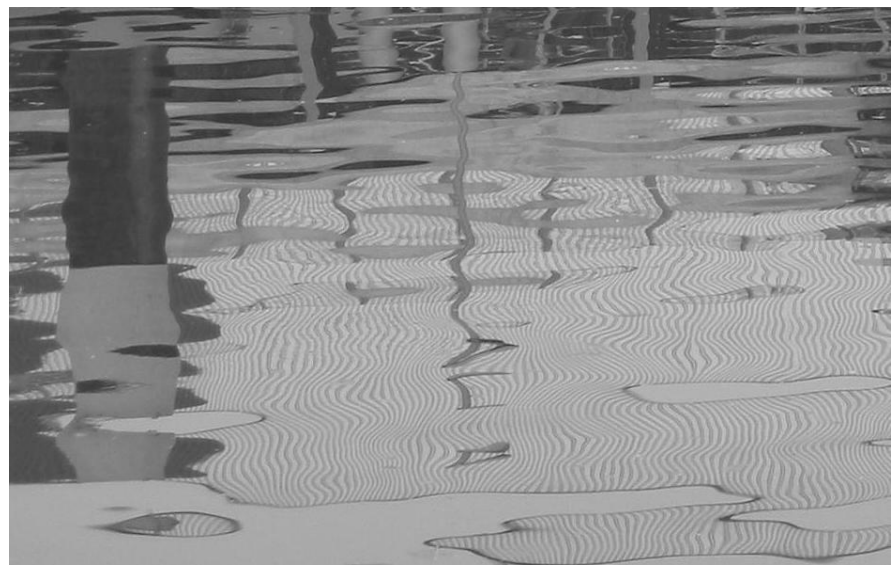

Fig. 2 Reflection fringes of periodic line structure on the building in Figl. Bottom part of photo taken by T. Bothe. 
Many of us are drawn to the images of fringes in our everyday lives, for observing fringes in our surroundings is, one may say, our professional deviation. With this conference we have continued the biannual "Fringe Art" competition to share our favorite fringe patterns. The winner will be announced in the next conference proceedings.

Until the next Interferometry conference, may you continue to see fringe patterns everywhere.

Joanna Schmit Katherine Creath Catherine Towers 
Downloaded From: https://www.spiedigitallibrary.org/conference-proceedings-of-spie on 26 Apr 2023

Terms of Use: https://www.spiedigitallibrary.org/terms-of-use 


\title{
Advanced and shaped light fields for the biosciences
}

\author{
Kishan Dholakia \\ SUPA, School of Physics and Astronomy, University of St Andrews, \\ Fife KY16 9SS, Scotland \\ e-mail:kd1@st-and.ac.uk
}

Advanced photonics using novel holographic beam shaping and interferometry has proved to be a powerful and emergent area in biophotonics. Light may be used in various guises. A prime example is optical micromanipulation. This is a powerful non-contact technique where micrometre sized particles can be grabbed, moved and generally manipulated solely with light. Optical tweezers is the most popular way to implement these forces using a single tightly focused light beam. They have forged an important bridge between physics, chemistry and biology. In recent years there has been a proliferation of activity in this area, fuelled, in part, by the recognition that we need to advance the "optical toolkit". This essentially means creating more elaborate $2 \mathrm{D}$ and $3 \mathrm{D}$ light patterns (beam shaping) that can create an optical landscape. Particle and cellular motion on such a landscape will enhance our ability to move and sort particles and importantly, create 2D and 3D arrays of particles [1].

Advanced beam shaping may also be considered useful for the topic of cell transfection. Here we consider the cell membrane which represents the outer extremity of all eukaryotic cells. In mammals, this is a thin $(5 \mathrm{~nm})$ bi-layer film of lipids, embedded with various protein molecules at interspersed locations. Under normal circumstances, the lipid nature of the cell membrane acts as an impermeable barrier to the passage of most water-soluble molecules. Thus, the selective introduction of therapeutic agents to the inside of dysfunctional or diseased cells remains problematic. Methods for puncturing the cell membrane without causing any collateral damage have been devised and importantly, this includes laser-assisted techniques particularly using multi-photon processes. Bessel modes can be used for "focus-free" photoporation (see fig.1) and offer new opportunities for the field [2]. This talk will cover both aspects of optical trapping, sorting and cell transfection using advanced beam shaping and interferometry.
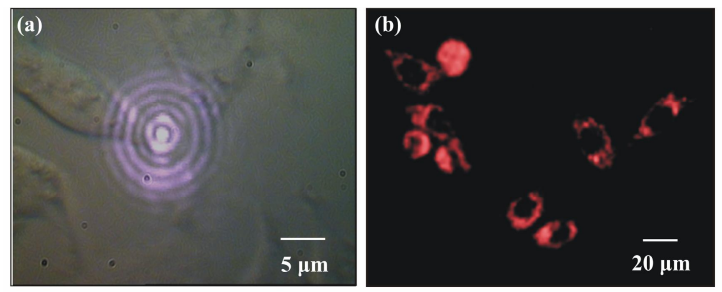

Figure 1. (a) The Bessel beam "focus" is positioned on the cell plane. (b) Upon successful transfection, the cells express the red fluorescent protein and fluoresce red (adapted from reference 2)

[1] "Optical Micromanipulation" K. Dholakia, P Reece and M Gu Chem. Soc. Rev, 37, 42 - 55 (2008)

[2] "Femtosecond cellular transfection using a non-diffracting light beam" X. Tsampoula, V. Garcés-Chávez, M. Comrie, D. Stevenson, M.B. Agate, F.J. Gunn-Moore, C.T.A. Brown and K Dholakia, Appl Phys Lett 91, 053902 (2007). 
Downloaded From: https://www.spiedigitallibrary.org/conference-proceedings-of-spie on 26 Apr 2023

Terms of Use: https://www.spiedigitallibrary.org/terms-of-use 